\title{
Manual and Automated Determination of Glucose in Blood with Glucose Oxidase and Molybdate/Iodide as Redox Catalyst
}

\author{
By Dušanka Mikac-Dević, H. Stanković and G. Würth \\ Medical Faculty, University of Zagreb, Hospital Dr. M. Stojanovic, Zagreb, Yugoslavia
}

(Eingegangen am 25. November 1971/20. April 1972)

\begin{abstract}
A method for glucose determination with glucose oxidase is proposed in which the redox catalyst Na-molybdate-KI replaces peroxidase. Whole blood $(100 \mu \mathrm{l})$ may be used after deproteinization; serum or plasma $(10 \mu \mathrm{l})$ can be analyzed directly. The color is stable for at least 30 minutes after stopping the reaction.
\end{abstract}

Es wird eine Methode zur Bestimmung von Glucose mit Glucoseoxidase vorgeschlagen, bei der der Redoxkatalysator Na-Molybdat/KI Peroxidase ersetzt. Vollblut $(100 \mu \mathrm{l})$ wird nach Enteiweißung, Serum bzw. Plasma $(10 \mu \mathrm{l})$ direkt analysiert. Der gebildete Farbstoff ist nach Abstoppen der Reaktion mindestens 30 Minuten stabil.

The oxidation of $\beta$-D-glucose by glucose oxidase to $\delta$-glucono-lactone which spontaneously hydrolyzes to D-gluconic acid has been widely and successfully used for the determination of glucose in clinical chemistry. The method is specific for glucose (1) and has replaced procedures employing unspecific redox systems. In the presence of peroxidase the $\mathrm{H}_{2} \mathrm{O}_{2}$ formed in the glucose oxidase reaction oxidizes a chromogen in amounts equimolar to glucose. The color is measured photometrically.

Several improvements to this method have been described. The widely used chromogen o-dianisidine has been replaced by noncarcinogenic substances such as ethylbenzthiazolinsulfonic acid (ABTS) (2), diethylphenylenediamine (DEPPD) (3) and the use of iodine in the presence of metallic ions has been suggested. Peroxidase has been replaced in some procedures by catalytic systems such as iodine-vanadate (5), ammoniummolybdate-iodine (3) or molybdic acid-iodine (4). KöHLer and Braunfeld in a critical review (6) gave preference to the use of peroxidase over nonenzymatic redox systems.

We have developed and used in our laboratory for two years a glucose oxidase method for the determination of glucose in which peroxidase is replaced by the redox system of iodine plus Na-molybdate. Only $100 \mu 1$ of blood or $10 \mu \mathrm{l}$ of serum or plasma are needed. The procedure requires only one pipetting step. The blank is zero. The reaction takes place in a weakly acid medium and is stopped by adjusting the $\mathrm{pH}$ to 12.7 .

\section{Materials and Methods}

Reagents

1. $\mathrm{Na}_{2} \mathrm{SO}_{4} 30 \mathrm{~g} / 1$

$\left.\begin{array}{l}\text { 2. } \mathrm{ZnSO}_{4} \cdot 7 \mathrm{H}_{2} \mathrm{O} 50 \mathrm{~g} / 1 \\ \text { 3. } \mathrm{NaOH} 0.25 \mathrm{~mol} / 1\end{array}\right\}$ neutralised

4. $\mathrm{NaOH} 100 \mathrm{~g} / \mathrm{l}$.

5. Na-molybdate-KI: $0.4 \mathrm{~g} \quad \mathrm{Na}_{2} \mathrm{MoO}_{4} \cdot 2 \mathrm{H}_{2} \mathrm{O}+8 \mathrm{~g}$ KI to $1000 \mathrm{ml} \mathrm{H}_{2} \mathrm{O}$.
6. Glucose oxidase (Pliva, Pharmaceutical Co. Zagreb), $1 \mathrm{mg}$ contains $4 \mathrm{I}$. U. of activity. $0.7 \mathrm{~g}$ of the enzyme are dissolved in a few milliliters of $0.2 \mathrm{~mol} / \mathrm{I}$ acetate buffer $\mathrm{pH} \mathrm{5.5}$, and diluted with the acetate buffer to 1 liter. It is filtered and kept in a dark bottle in a refrigerator. The solution is stable for two weeks.

7. 0 -Dianisidine. $0.6 \mathrm{~g}$ of $o$-dianisidine is dissolved in $10 \mathrm{ml} 1 \mathrm{~mol} / \mathrm{l}$ $\mathrm{HCl}$ and diluted to $100 \mathrm{ml}$ with $\mathrm{H}_{2} \mathrm{O}$. In the refrigerator the solution is stable for 10 days. Every day $5 \mathrm{ml}$ is diluted with $20 \mathrm{ml}$ of $\mathrm{H}_{2} \mathrm{O}$.

8. Standard solution of glucose in $1 \mathrm{~g} / \mathrm{l}$ benzoic acid.

9. Mixed reagent. To be prepared daily in the amount required; it consists of:

$400 \mathrm{ml} \mathrm{Na}$-molybdate- $\mathrm{KI}$ (reagent 5)

$400 \mathrm{ml}$ glucose oxidase (reagent 6 )

$40 \mathrm{ml}$ diluted o-dianisidine (reagent 7).

For Clinomak the mixed reagent is diluted with an equal amount of water before use.

\section{Procedure}

Blood is deproteinized by adding $100 \mu \mathrm{l}$ blood to a mixture of $1 \mathrm{ml}$ of isotonic Na-sulfate, $200 \mu \mathrm{l}$ of $50 \mathrm{~g} / \mathrm{l}$ zinc sulfate and $200 \mu \mathrm{l}$ of $0.25 \mathrm{~mol} / \mathrm{l} \mathrm{NaOH}$. After centrifugation $200 \mu \mathrm{l}$ of the supernatant is added to $1.5 \mathrm{ml}$ of the mixed reagent.

Deproteinization is omitted with serum and plasma, $10 \mu \mathrm{l}$ of which are directly added to $1.5 \mathrm{ml}$ of the mixed reagent (reagent 9). After exactly $20 \mathrm{~min}$ the reaction is stopped by adding one drop of $100 \mathrm{~g} / 1 \mathrm{NaOH}$. Blanks and standards are treated simultaneously. Readings are made at $460 \mathrm{~nm}$.

Procedure for the Clinomak autoanalyzer

$100 \mu \mathrm{l}$ of deproteinized supernatant (see above) or $10 \mu \mathrm{l}$ of serum or plasma are aspirated. Valve 1 is set in position 4 for the mixed reagent; the reading is taken at $460 \mathrm{~nm}$ during the second cycle.

Digital readouts are obtained with the Datamak with a standard solution of $800 \mathrm{mg} / 1$ glucose. In each series are included "pooled serum" and several standards of higher concentrations as controls.

\section{Results and Discussion}

Only $10 \mu \mathrm{l}$ of serum or plasma, which may be obtained from capillary blood, are needed for the determination of glucose. The interference by glutathione, cysteine and some other substances which are present in blood in higher concentrations than in serum or plasma is thereby diminished. 
The stability of glucose is ensured by using the same preservative (see below) for plasma as for whole blood. The influence of uric acid and creatinine was checked using the method both with and without deproteinization. When added to blood, serum or plasma up to $160 \mathrm{mg} / \mathrm{l}$ of uric acid and up to $30 \mathrm{mg} / \mathrm{l}$ of creatinine were without noticeable effects on the final results.

\section{Preservatives}

For blood and plasma we use Na-fluoride (1 part) + EDTA (3 parts) at a concentration of $20 \mathrm{mg} / \mathrm{ml}$ of blood.

\section{Deproteinisation}

Somogyr reagent is used because acid agents such as trichloroacetic acid or perchloric acid are not suitable in the further steps of the reaction. Zinc sulfate and sodium hydroxide must be neutralised titrimetrically.

\section{Glucose oxidase}

Glucose oxidase from Aspergillus niger was obtained from Pharmaceutical Co. Pliva Zagreb. Comparative analyses of the same samples with glucose oxidase of equivalent activity from "Pliva" and "Merck" gave identical results.

\section{Na-molybdate-KI}

This system was a suitable replacement for peroxide. Na-molybdate permits a homogeneous solution and there was no interference with the chromogen.

\section{o-Dianisidine}

o-Dianisidine reagent, prepared by dissolving the compound in hydrochloric acid, shows less tendency to subsequently form precipitates than the reagent solutions in acetone or alcohol. Benzidine and ABTS did not react under these circumstances. With $m$ phenylendiamine a green color develops, which is of lower intensity compared to o-dianisidine.

\section{Absorbance}

The extinction, measured from 400 to $540 \mathrm{~nm}$ has a maximum at $460 \mathrm{~nm}$.

\section{LAMBERT-BeER lan}

The standard curve is linear up to $3.00 \mathrm{~g} / 1$. The line has an ideal angle of 45 degrees. A slight turbitity develops with concentrations exceeding $30.00 \mathrm{~g} / \mathrm{l}$ (Fig. 1).

\section{Precision of the method}

20 samples of a specimen with a mean value of $960 \mathrm{mg} / 1$ gave S. D. $= \pm 2.2$.

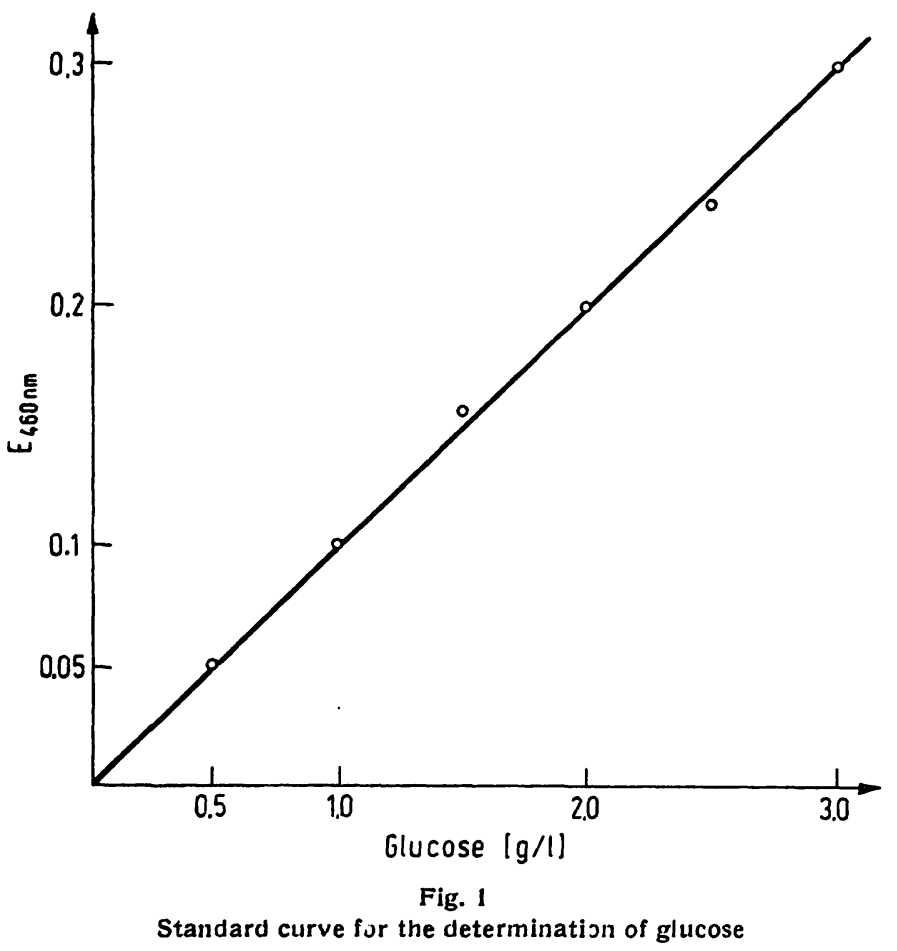

\section{Comparison of the method}

The proposed method has been compared with the glucose oxidase method of Boehringer Mainheim Co. In 60 parallel determinations the values ranged from 600 to $2560 \mathrm{mg} / \mathrm{l}$. Statistical evaluation of these results by STUDENT's test gave no significant differences of the results $\left(t=1.18, t_{\text {theor. }}=1.68\right)$.

\section{Test recovery}

Recovery of added glucose was nearly $100 \%$ (Tab. 1).

Tab. 1

Recovery test

\begin{tabular}{ccccc}
\hline $\begin{array}{c}\text { Results } \\
\text { glucose } \\
\mathrm{g} / \mathrm{l}\end{array}$ & $\begin{array}{c}\text { Added } \\
\text { glucose } \\
\mathrm{g} / \mathrm{l}\end{array}$ & $\begin{array}{c}\text { Concen- } \\
\text { tration } \\
\text { measured } \\
(\mathrm{g} / \mathrm{l})\end{array}$ & $\begin{array}{c}\text { Theoretical } \\
\text { concen- } \\
\text { tration } \\
(\mathrm{g} / \mathrm{l})\end{array}$ & $\begin{array}{c}\% \\
\text { Recovery }\end{array}$ \\
\hline 1.02 & 0.50 & 1.50 & 1.52 & 98 \\
1.02 & 1.00 & 1.98 & 2.02 & 98 \\
1.02 & 2.00 & 3.02 & 3.02 & 100 \\
1.02 & 3.00 & 4.05 & 4.02 & 100.7 \\
\hline
\end{tabular}

\section{Normal values}

In 40 persons in good healthy conditions a mean value of $740 \mathrm{mg} / \mathrm{l}$ with a range from 510 to $970 \mathrm{mg} / \mathrm{l}$ was found. Blood was used to determine the normal values.

\section{References}

1. Washoo, M. E. and E. W. Rice, Clin. Chem., New York 7, 542 (1962). - 2. Kable, K., L. Weiss, M. Klarwein and O. Wieland, Z. analyt. Chem. 252, 228 (1970). - 3. ThOMPSON, R. H., Clin. Chim. Acta, Amsterdam 25, 475 (1969). - 4. Aw,
S. E., Clin. Chim. Acta, Amsterdam 26, 235 (1969). - 5. Härtel, A., K. FABEL-SChulte, H. LANG and W. RICK, this journal 6, 34 (1968). - 6. KöhleR, P. and H. BAufeld, Z. med. Labortechn. 10, 102 (1969). 